\title{
Retinoinvasive malignant melanoma of the uvea
}

Tero Kivelä, Paula Summanen

\begin{abstract}
Aims-To define a retinoinvasive phenotype of uveal melanoma based on an informative case and survey of literature. Methods-A 65-year-old woman developed a circumscribed mixed cell type melanoma of the ciliary body that was locally excised. After 6 years, secondary glaucoma evolved. Three years later a ring melanoma was diagnosed and the eye was enucleated. The histopathological material was analysed by immunohistochemistry.
\end{abstract}

Results-A spindle cell type ring melanoma infiltrated the iris and ciliary body diffusely, and extended through the aqueous outflow channels and iridocyclectomy flap extrasclerally. The choroid was uninvolved. Instead, tumour cells spread to the vitreous and along the ciliary epithelium, adhered to the hyaloid face and retinal surface, and extensively invaded the neuroretina, the retrobulbar optic nerve, and perineural space. They were labelled for S-100 protein, vimentin, and in the neuroretina for cytokeratins 8 and 18. No evidence of systemic disease is evident 5 years after enucleation. Three identical tumours of the iris and ciliary body that extensively infiltrated the neuroretina and retrobulbar optic nerve were identified from previous literature.

Conclusion-Retinoinvasive melanoma is a rare but distinct phenotype of uveal melanoma, different from circumscribed and most diffuse melanomas that may erode the overlying retina and infiltrate the optic nerve but that do not invade non-adjacent retina. Retinoinvasive tumours tend to evolve from a ring melanoma and they grow slowly, which may favour emergence of tumour clones able to migrate, adhere to, and invade into the neuroretina, analogous to the metastatic cascade. Frequent secondary angle closure glaucoma may promote invasion into the optic nerve.

(Br f Ophthalmol 1997;81:691-697)

Choroidal melanomas rather frequently erode radially into the overlying neuroretina when they have broken through Bruch's membrane. ${ }^{1-6}$ Such limited retinal invasion occurs in $23 \%$ to $40 \%$ of eyes enucleated because of choroidal melanoma. ${ }^{2}{ }^{35-7}$ It is most frequent close to the optic disc and ora serrata, where the retina is relatively fixed. ${ }^{135}$ These uveal melanomas may also seed the subretinal space, ${ }^{8}$ the vitreous, ${ }^{5910}$ and the surface of the retina. ${ }^{1} 8^{11-17}$ The inner retina resists infiltration, however. ${ }^{15}$ Uveal melanomas also show little if any tendency to horizontally invade non-adjacent retina. ${ }^{1568121315-17}$

Likewise, most uveal melanomas spare the optic nerve. ${ }^{25}{ }^{18-20}$ When they extend outside the eye, they generally do so along ciliary vessels and nerves. ${ }^{511}{ }^{21}$ Infiltration of the optic nerve proper is not, however, entirely exceptional. ${ }^{23} 5^{10-12}{ }^{18-38}$ It is reportedly seen in $2 \%$ to $5 \%$ of all enucleated eyes with a uveal melanoma, ${ }^{23518192531-33}$ and in 5\% to $62 \%$ of eyes in which the tumour is located adjacent to the optic disc. ${ }^{35182736}$ In rare instances, the neoplastic cells may even extend to the optic chiasm and cause a visual field defect in the fellow eye. ${ }^{202329} 38$ Optic nerve invasion is enhanced by concomitant glaucoma. ${ }^{32}$

The purpose of the present study is to describe in detail a melanoma of the ciliary body and iris that did not invade the choroid, but extended outside the eye by invading the retina and optic nerve. We also draw attention to three identical tumours in previous literature. ${ }^{23252729}$ Based on these data, we define the retinoinvasive uveal melanoma as an entity that differs from ordinary diffuse uveal melanomas. ${ }^{111} 12263537$ We suggest that it represents a distinct, albeit seldom travelled, path of tumour progression that imitates the metastatic cascade.

\section{Materials and methods}

CASE REPORT

In April 1983, a 65-year-old white woman noted a pigmented fleck on the lower nasal quadrant of her iris (Fig 1A). In December, gonioscopy (Fig 1B) and fluorescein angiography revealed a vascularised tumour of the ciliary body that was diagnosed as melanoma. It was circled with cryotherapy and removed a month later by iridocyclectomy. It was found to be a mixed cell type melanoma.

The tumour margins were not all unequivocally free. Residual tumour could not be seen, however, and careful follow up only was recommended. Semiannual examinations revealed no recurrence. In 1989, the intraocular pressure rose and dispersed pigment was seen in the chamber angle. The pressure did not respond to medication or cyclocryotherapy. In 2 years the eye lost light perception.

In 1992, several lightly pigmented nodules appeared close to the limbus (Fig 1C). A biopsy was not diagnostic because of crush artefact. The nodules slowly increased in size and recurrent tumour was now seen in the ciliary body. A second biopsy in June 1992 confirmed recurrent melanoma. No tumour
Accepted for publication 28 April 1997 
was seen in the posterior pole in repeated examinations, but visibility was poor.

The blind eye was enucleated with a wide conjunctival margin in August 1992. Unexpectedly, a large part of the retrobulbar optic nerve was black and tumour was found in the subarachnoid space (Fig 1D). The cut surface of the nerve was free of tumour. Histopathology confirmed the presence of a ring melanoma perforating the limbus. The patient declined suggested radiotherapy.

Computed tomography 1 year later revealed no evidence of orbital recurrence. A clinically suspicious, small pigmented conjunctival spot was excised in October 1993, revealing residual melanoma. In April 1997, the patient is without any clinical or radiological evidence of further local or systemic disease.

\section{METHODS FOR HISTOPATHOLOGY}

All excised tissues and the enucleated eye were formalin fixed and paraffin embedded. Routine stains included haematoxylin and eosin and van Gieson. The retinal pigment epithelium (RPE) was used as an internal positive control for cytokeratin (CK) 8 and $18,{ }^{39}$ vascular endothelial cells for vimentin, and retinal glia for glial fibrillary acidic protein (GFAP) and the HNK-1 carbohydrate epitope. ${ }^{40}$

Sections, $5 \mu \mathrm{m}$ thick, were cut on chromium gelatin coated glass slides and immunostained with the avidin-biotinylated-peroxidase complex method (Vectastain ABC Elite Kits, mouse and rabbit IgG, Vector Laboratories, Burlingame, CA, USA) as has been described. ${ }^{39}{ }^{40}$ To enable evaluation of the positive immunoreaction in pigmented cells, 3,3'diaminobenzidine tetrahydrochloride was used as chromogen. ${ }^{39}$ Melanin was then bleached by incubating the sections with $3.0 \%(\mathrm{v} / \mathrm{v})$ hydrogen peroxide and $1.0 \%(\mathrm{w} / \mathrm{v})$ disodium hydrogen phosphate for 18 hours at room temperature. ${ }^{41}$

Primary mouse monoclonal antibodies (Mab) CAM 5.2 to CK 8 (IgG2a, Lot P0522, Becton Dickinson, Mountain View, CA, USA, diluted 1:2), ${ }^{39}$ CY-90 to CK 18 (IgG1, Lot 70H-4866, Sigma, St Louis, MO, USA, $1: 3000),{ }^{39}$ Vim 3 B4 to vimentin (IgG2a, Lot 11454324-01, Boehringer Mannheim, Mannheim, Germany; 1:50), and HNK-1 to the HNK-1 carbohydrate epitope (Anti-Leu-7, IgM, Lot 30015, Becton Dickinson, 1:25) were obtained commercially. Rabbit antisera to GFAP (Lot 119, 1:1000) and S-100 protein (Lot 026, 1:1000) were bought from Dakopatts (Glostrup, Denmark).

The sections were pretreated with $0.4 \%$ $(\mathrm{w} / \mathrm{v})$ pepsin to reduce background and to enhance the intensity of specific staining when antibodies to intermediate filaments were used. ${ }^{39}$ Omitting the primary or secondary antibody or the ABC complex resulted in loss of all immunoreaction. Sections stained with different antibodies of the same isotype were carefully compared to exclude non-specific binding of antibodies representing that isotype, and normal rabbit serum was used as a negative control with the polyclonal antisera.
LITERATURE SURVEY

A Medline search using the keywords melanoma, retina, vitreous, and optic nerve was conducted for the years 1962-96. Hand searching of older reports was done using the papers found, textbooks, and several indices as starting points. Pertinent original papers were reviewed for data on retinal and optic nerve invasion.

\section{Results}

HISTOPATHOLOGY

The iridocyclectomy specimen was a $6 \times 8 \mathrm{~mm}$ deeply pigmented tumour with adjacent sclera. Pigmented, non-cohesive epithelioid cells and large and plump spindle cells were present (Fig 2A). Where the tumour infiltrated the base of the iris, the cells were smaller and more uniform in shape. Areas of necrosis and haemorrhage from preceding cryotherapy were found (Fig 2A). The tumour reacted for S-100 protein and for vimentin with Mab Vim 3B4, but not with Mab CAM 5.2 and CY-90 to CK 8 and 18.

The second biopsy of a limbal nodule, $3 \mathrm{~mm}$ in size, contained smaller and more cohesive, irregularly polygonal cells that largely lacked pigment, and reacted for S-100 protein and for vimentin (Fig 2B), but not for CK 8 and 18 .

The enucleated eye measured $23 \times 24 \mathrm{~mm}$. Variably pigmented limbal nodules were present, the largest were 4.5 and $6 \mathrm{~mm}$ in size. The optic nerve stump was $13 \mathrm{~mm}$ long and abnormally dark and thick, measuring $5 \mathrm{~mm}$ in diameter (Fig 1D). On sectioning the eye, a ring melanoma of the ciliary body and iris (Fig 1E), multiple retinal haemorrhages, and pale tumour nodules over and within the retina were noted (Fig 1F). The ring melanoma consisted of non-pigmented spindle cells (Fig 2C) unlike its iridocyclectomised predecessor (Fig 2A). They reacted for S-100 protein and for vimentin, but no unequivocal labelling for CK 8 and 18 was present.

Tumour cells extended as a sheet along the endothelium of the peripheral cornea and adhered as aggregates to the central endothelium. They perforated the sclera at multiple sites through the iridocyclectomy flap and via aqueous outflow channels (Fig 1E). The tumour replaced the pars plicata and the anterior pars plana, but did not involve the posterior pars plana or choroid (Fig 2D). Instead, it grew along the ciliary epithelium (Fig 2D) and detached to the vitreous (Fig 2E) that had guided cells to peripheral retina (Fig $2 \mathrm{~F})$. The vitreous base was uninvolved.

Most of the optic nerve was replaced by melanoma (Fig 2G). Only scattered myelinated axons remained. The tumour extended to the perineural space. It did not react for CK 8 and 18 . The later orbital biopsy contained a small focus of melanoma (Fig $2 \mathrm{H}$ ). The cells were epithelioid in type with abundant eosinophilic cytoplasm and often semilunar nuclei that were pushed to one side (Fig $2 \mathrm{H}$ ). Little evidence of infiltration of surrounding tissues and no mitoses were found. Many cells reacted for CK 8 and 18 (Fig 2I), respectively, in addition to $S-100$ protein and vimentin. 

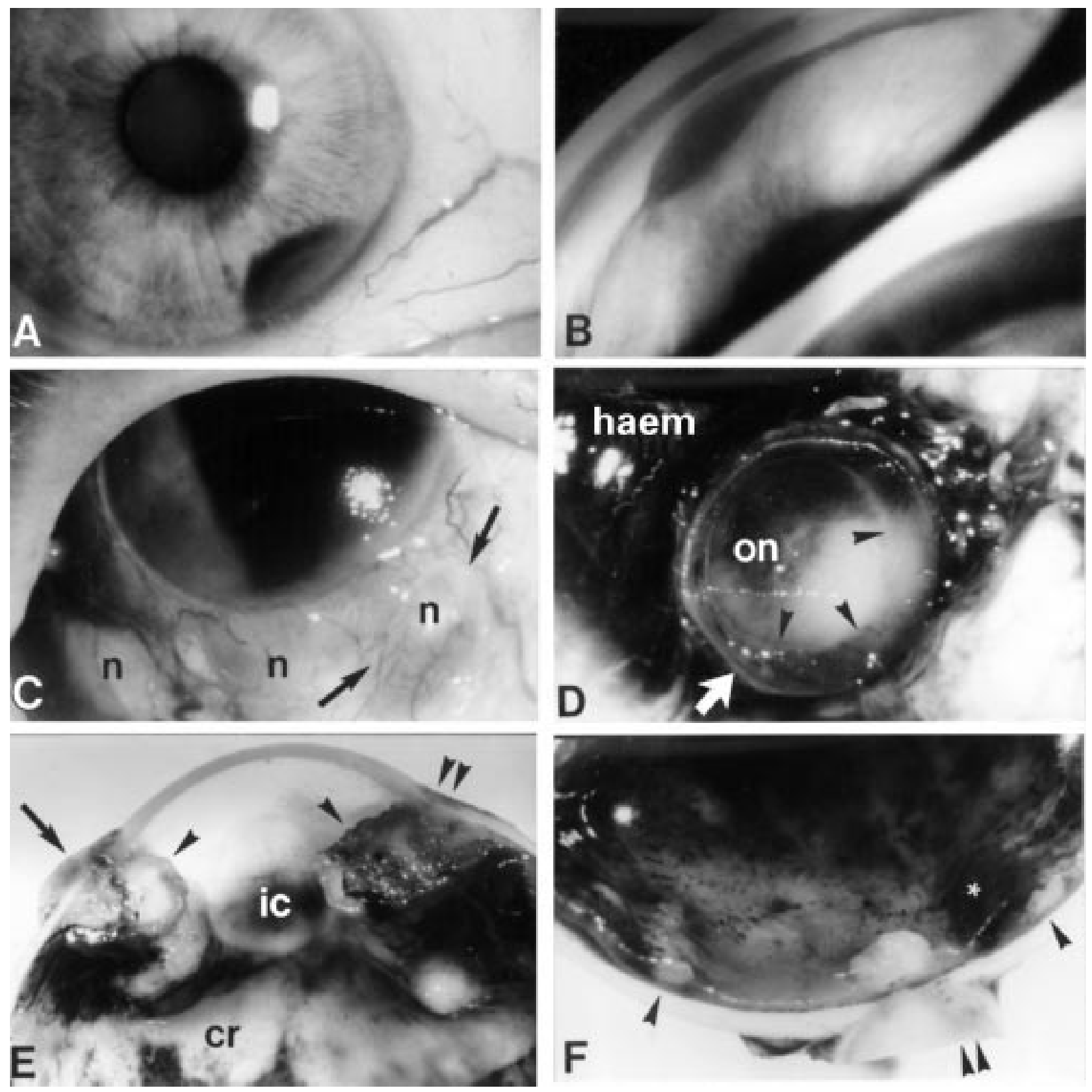

Figure 1 Clinical and macroscopic findings of retinoinvasive uveal melanoma. (A) The initial pigmented tumour at the base of the iris. (B) The adjacent chamber angle is uninvolved. (C) Amelanotic episcleral nodules ( $n$ ) are seen 9 years later, the largest is at the site of the iridocyclectomy (between arrows). (D) The optic nerve (on) and space between the pia (arrowheads) and dura (white arrow) are largely replaced by tumour; the episclera is dark from haemorrhage (haem; $\times 8)$. (E) Iris and ciliary body are replaced by tumour (arrowheads) that perforates the sclera through the iridocyclectomy flap (arrow) and along aqueous channels (double arrowhead). Note coloboma from iridocyclectomy (ic) and scars from cryocoagulation (cr) ( $\times 5)$. ( $F$ ) Scattered intraretinal tumour nodules (arrowheads) and small dark haemorrhages; note a larger nodule in front of the thickened optic nerve (double arrowhead), and blood under the inner limiting membrane (asterisk) ( $\times 6)$.

Mostly spindle-shaped tumour cells extensively invaded the neuroretina. They grew as variably thick epiretinal membranes (Fig 3A), under the inner limiting membrane (Fig 3B), along the posterior hyaloid face (Fig 3C), formed nodules within the retina (Fig 3D,E), and eroded up to Bruch's membrane (Fig 3F). They invaded the retina preferably close to blood vessels and formed perivascular collars (Fig 3E) and single files on either side of inner limiting membrane (Fig 3B). Many intraretinal tumour cells reacted for CK 8 and 18 (Fig 3G) in addition to vimentin and S-100 protein. The retina showed secondary gliosis, cystic oedema, intraretinal haemorrhages (Fig
3C,D), and a haemorrhagic detachment of the inner limiting membrane (Fig $1 \mathrm{~F}$ ). Antibodies to GFAP and the HNK-1 carbohydrate epitope (Fig $3 \mathrm{H}$ ) revealed that little if any mixing of neoplastic cells and retinal glia had occurred.

\section{Discussion}

Invasion through the vitreous and retina into the retrobulbar optic nerve of a ciliary body melanoma is unique. Nevertheless, we were able to identify three almost identical tumours, the first one reported by Terry in 1940, with a systematic literature survey (Table 1). A ring melanoma of the ciliary body, uninvolved 

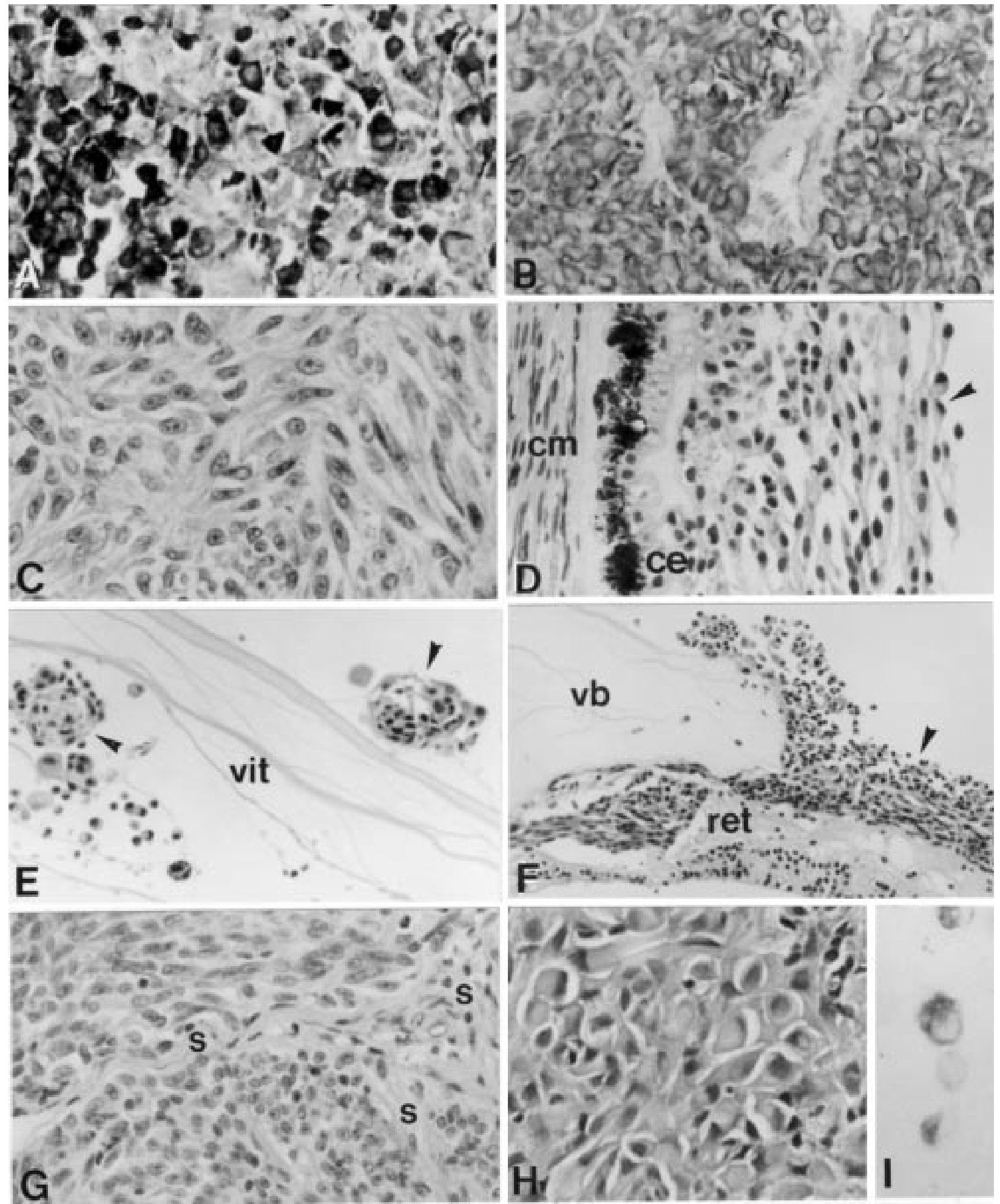

Figure 2 Evolution of the ciliary body melanoma ( $A, C-H$, haematoxylin and eosin; $B, I$, immunoperoxidase). (A) The initial tumour contains pigmented, pleomorphic epithelioid cells $(\times 340)$. (B) The limbal nodule consists of small epithelioid cells that react with MAb Vim $3 B 4$ to vimentin $(\times$ 360). (C) The iris and anterior ciliary body are replaced by spindle cell melanoma $(\times 380)$. (D) The tumour (arrowhead) grows as a sheet on the ciliary epithelium (ce), but the ciliary muscle $(\mathrm{cm})$ and stroma are uninvolved $(\times 250)$. (E) The tumour (arrowheads) grows in the anterior vitreous (vit) $(\times$ 210). (F) It extends along the hyaloid membrane (arrowhead) to the vitreous base (vb) and invades the peripheral retina $(r e t)(\times 140)$. (G) It fills the spaces between the septa (s) of the optic nerve normally occupied by nerve fibre bundles $(\times 280)$. (H) The residual orbital tumour consists of epithelioid cells with eccentric, often semilunar nuclei (× 450). (I) Some are labelled with MAb CY-90 to CK 18 ( $\times 480)$.

choroid, $^{232529}$ invasion of anterior sclera ${ }^{2325} 29$ and secondary glaucoma, ${ }^{25}{ }^{29}$ retrocorneal tumour growth, ${ }^{25}$ vitreous seeding ${ }^{25}$ invasion of retina preferably adjacent to vessels, ${ }^{23}{ }^{25}$ intraretinal haemorrhages, ${ }^{2325}$ growth on the optic disc ${ }^{23} 25$ with invasion of the retrobulbar nerve ${ }^{232529}$ and perineural space, ${ }^{25}$ and eventual loss of light perception ${ }^{25}{ }^{29}$ were common to them. This phenotype, characterised in particular by widespread invasion of non-adjacent 

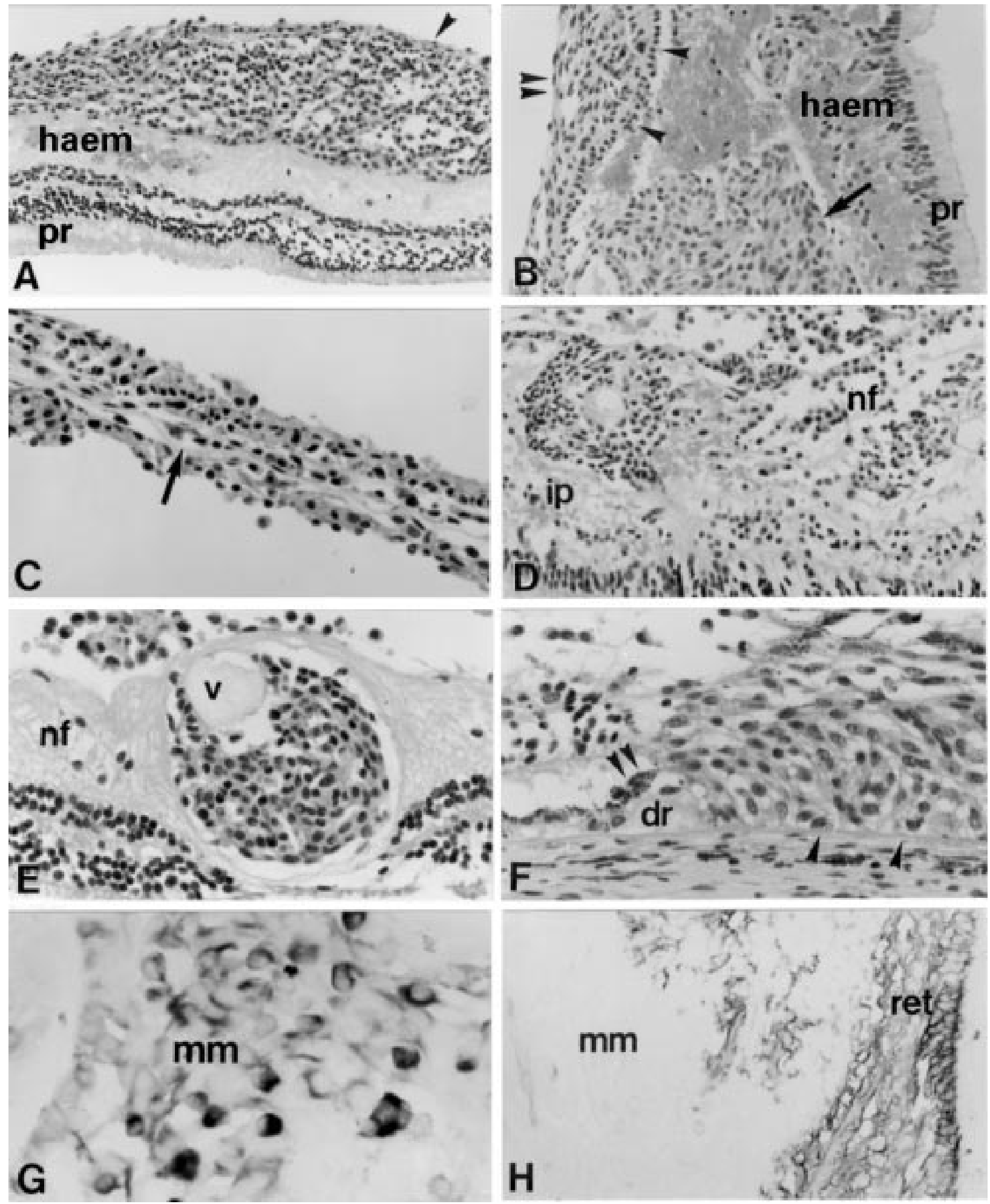

Figure 3 Invasion of the retina by uveal melanoma ( $n f$, nerve fibre; $i p$, inner plexiform; and pr, photoreceptor layer; $A-F$, haematoxylin and eosin; $G, H$, immunoperoxidase). (A) Epiretinal melanoma (arrowhead) and intraretinal haemorrhages (haem) are seen $(\times 140)$. (B) Invading melanoma cells (double arrowhead) align under the inner limiting membrane (arrowheads) and grow as nodules (arrow) among intraretinal haemorrhages (haem) $(\times$ 230). (C) The tumour also grows along the posterior hyaloid membrane $(\times 280)$. (D) Nodular and diffuse infiltration of the neuroretina $(\times 230)$. (E) Tumour grows around blood vessels (v) within the retina $(\times 280)$. (F) It replaces the RPE (double arrowhead) but spares Bruch's membrane (arrowheads); dr, drusen $(\times 340)$. (G) Melanoma cells $(\mathrm{mm})$ react with MAb CY-90 to CK $18(\times 420)$. (H) They are not labelled for the HNK-1 epitope that highlights displaced retinal glia (ret) instead $(\times 230)$.

retina and optic nerve, could aptly be designated retinoinvasive.

Many uveal melanomas that invade the optic nerve, including most retinoinvasive ones (Table 1), share a set of features postulated by
Spencer. ${ }^{29}$ They contain non-cohesive epithe-

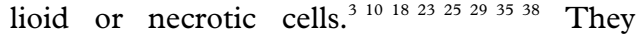
often spread to the optic nerve through the vitreous rather than by direct continuity. ${ }^{102529}$ However, direct optic nerve invasion by 


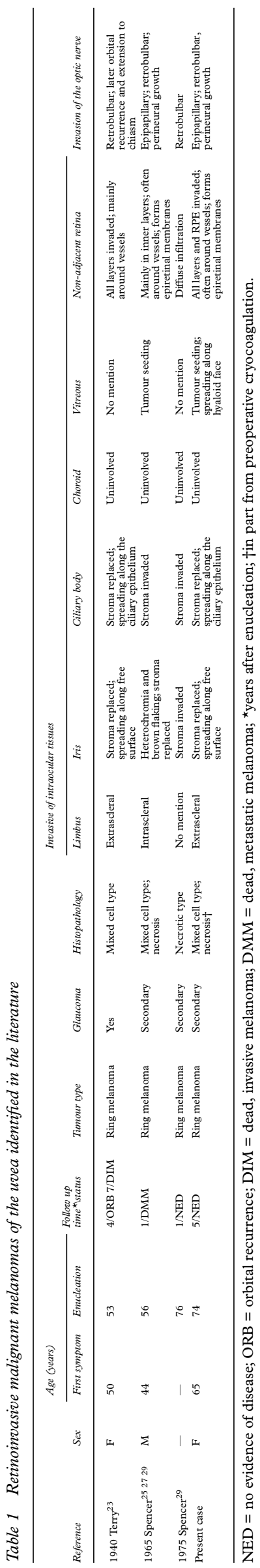

tumours originating adjacent to the optic disc is also rather common. ${ }^{3518} 27{ }^{36}$ Finally, secondary angle closure glaucoma ${ }^{1025} 293538$ diverts aqueous with neoplastic cells posteriorly and weakens the optic nerve by causing ischaemia and oedema. ${ }^{29}$ Loss of light perception alerts the clinician to optic nerve invasion. ${ }^{3} 1025293538$ These factors do not, however, explain invasion of non-adjacent retina.

Spencer mentioned that tumour cells invading the optic nerve might specifically adhere to it. ${ }^{29}$ Today one would give even more emphasis to properties of tumour cells and of tissues they invade rather than to mechanical factors. ${ }^{42-45} \mathrm{As}$ in metastatic cascade, retinoinvasive tumour cells must detach from their primary tumour by altering their interaction with the extracellular matrix. ${ }^{42}$ They must adhere to the inner limiting membrane, digest it, migrate into the retina, and proliferate within it. ${ }^{42-44}$

Metastases probably start when tumour cells bind to the vascular endothelium of susceptible organs. ${ }^{44}$ This is how occasional cutaneous melanomas will metastasise to the neuroretina. ${ }^{46-50}$ Further growth depends on interaction with the local microenvironment and on natural immunity of the host tissue. ${ }^{43-45}$ In the present case, single file formation along the inner limiting membrane is indicative of binding to the retina. In contrast, the choroid seems to form a barrier which many ring $^{1}$ and all retinoinvasive melanomas so far reported have been unable to trespass. ${ }^{2325} 29$ Intriguingly, electron microscopy and immunohistochemistry have recently revealed uveal compartments not visible by routine light microscopy ${ }^{40} 51$ that might influence tumour invasion.

Interestingly, whereas Mab CAM 5.2 and CY-90 to CK 8 and 18 did not label the initial ciliary body tumour and the ring melanoma, many intraretinal cells were immunoreactive. Perhaps retinal microenvironment had induced cytokeratins, or a tumour cell clone that expressed them was especially capable of invading the retina. On balance, every other primary uveal melanoma contains some cells that react for CK 8 and $18 .^{52}$

Because random mutations are responsible for tumour progression, ${ }^{42}{ }^{43}$ uveal melanomas should be able to acquire either some or all of the above properties. If so, some should adhere to and migrate on the retina, but fail to invade into it. Tumours that have negotiated these two steps are indeed on record. ${ }^{8}{ }^{12-17}$ Like retinoinvasive melanomas, ${ }^{23} 25$ they have often grown adjacent to retinal vessels ${ }^{14}{ }^{15}$ because nutrition here is better or resistance to invasion is weaker. Only limited infiltration into the superficial retina has been noted, ${ }^{13} 14{ }^{16}$ unlike in retinoinvasive melanomas.

Retinoinvasive melanomas spread widely within the eye, which suggests a relation with diffuse uveal melanomas: ring melanomas of the ciliary body and flat choroidal tumours involving at least one fourth of the uvea. ${ }^{11}{ }^{12} 26$ However, diffuse choroidal melanomas that have shed cells to the vitreous cavity and onto the inner limiting membrane apparently did not invade the retina ${ }^{512}$ and thus did not 
exhibit retinoinvasive properties. The histopathology in our case suggests an origin from a spindle cell ring melanoma that spawned a rapidly growing epithelioid tumour and then took a retinoinvasive phenotype. Much less likely, residual cells from a circumscribed epithelioid cell tumour developed into spindle cell retinoinvasive ring melanoma. The other retinoinvasive melanomas apparently also evolved from a ring melanoma (Table 1).

Time is probably important for the development of the retinoinvasive phenotype. Analogous to many diffuse melanomas, ${ }^{11} 12262837$ a long delay in diagnosis and, apparently, slow growth are typical. ${ }^{2325} 29$ The tumour has time to spread locally, to cause secondary glaucoma that facilitates posterior dissemination, and to develop unusual clones of neoplastic cells. ${ }^{813}$ Two retinoinvasive tumours proved fatal, one from intracranial growth of an orbital recurrence 7 years after enucleation indicating slow growth, ${ }^{23}$ and the other from metastases 1 year after enucleation. ${ }^{25} 29$ Thirteen years after iridocyclectomy and 5 years after enucleation our patient is alive without evidence of recurrence.

This work was supported by grants from the Paulo Foundation and Helsinki University Central Hospital (TYH0026).

1 Fuchs E. Über Pigmentierung, Melanom und Sarkom der Aderhaut. Arch Ophthalmol (Berlin) 1917;94:43-106.

2 Jensen OA. Malignant melanomas of the uvea in Denmark 1943-1952. A clinical, histopathological, and prognostic
study. Acta Ophthalmol (Copenh) (Suppl) 1963;75:1-220.

3 Study. Acta Ophthalmol (Copenh) (Suppl) 1963;75:1-220. mas. Extension along the optic nerve and its sheaths. Arch mas. Extension along the op
Ophthalmol 1978;96:440-5.

4 Augsburger JJ, Golden MI, Shields JA. Fluorescein angiography of choroidal malignant melanomas with retinal invasion. Retina 1984;4:232-41.

5 Rohrbach JM, Steuhl KP, Kreissig I, Thiel H-J. Epidemiologie, Invasion und Wachstum nicht-iridaler Aderhautmelanome und assoziierte intraokulare Veränderungen: Histologische Untersuchung von 233 Augen. Klin Monatsb Augenheilkd 1990;197:455-65.

6 Robertson DM, Campbell RJ, Weaver DT. Residual intrascleral and intraretinal melanoma: a concern with lamellar sclerouvectomy for uveal melanoma. Am 7 Ophthalmol 1991;112:90-3

7 Davies WS. Malignant melanomas of the choroid and ciliary body. A clinicopathologic study. Am f Ophthalmol 1963;55: 541-6.

8 Wolter JR. Fluid state of malignant choroidal melanoma growth presenting as exudative retinal detachment. Ophgrowth presenting as exudati
thalmologica $1989 ; 199: 34-40$.

9 Dunn WJ, Lambert HM, Kincaid MC, Dieckert JP, Shore JW. Choroidal malignant melanoma with early vitreous seeding. Retina 1988;8:188-92.

10 Al-Haddab S, Hidayat A, Tabbara KF. Ciliary body melanoma with optic nerve invasion. $\mathrm{Br}$ f Ophthalmol 1990;74:123-4.

11 Duke-Elder S. System of ophthalmology. Vol IX. London: Henry Kimpton, 1966:858-70

12 Font RL, Spaulding AG, Zimmerman LE. Diffuse malignant melanoma of the uveal tract: a clinicopathologic report of 54 cases. Trans Am Acad Ophthalmol Otolaryngol 1968;72:877-95.

13 Vrabec F. Les cultures intra-oculaires spontanées des mélanoblastomes de l'uvée. Arch Ophtalmol 1967;27:15966.

14 Daicker B. Melanosis retinae et papillae durch transretinal in den Glaskörper eingebrochenes malignes Aderhautin den Glaskorper eingebrochenes maligne

15 Eagle RC, Shields JA. Pseudoretinitis pigmentosa secondary to preretinal malignant melanoma cells. Retina 1982;2:51to

16 Champion R, Daicker B. Epiretinale Tumormelanose. Klin Monatsbl Augenheilkd 1983;182:502-5.

17 Laqua H, Völcker HE. Pars plana vitrectomy in eyes with malignant melanoma. Graefes Arch Clin Exp Ophthalmol 1983;220:279-84.

18 Samuels B. Anatomic and clinical manifestations of necrosis in eighty-four cases of choroidal sarcoma. Arch Ophthalmol 1934;11:998-1027.

19 Wilder HC, Paul EV. Malignant melanoma of the choroid and ciliary body: a study of 2,535 cases. Milit Surg $1951 ; 109 \cdot 370-8$
20 Reese AB. Tumors of the eye. 2nd ed. New York: Harper and Row, 1963:232-61.

21 Affeldt JC, Minckler DS, Azen SP, Yeh L. Prognosis in uveal melanoma with extrascleral extension. Arch Ophthalmol 1980;98:1975-9.

22 Byers WGM, MacMillan JA. Treatment of sarcoma of the uveal tract. Arch Ophthalmol 1935;14:967-74.

23 Terry TL. Malignant melanoma-so-called sarcoma-of uvea. III Extension into the optic nerve. Arch Ophthalmol 1940;24:206-14.

24 Callender GR, Wilder HC, Ash JE. Five hundred melanomas of the choroid and ciliary body followed five years or longer. Am f Ophthalmol 1942;25:962-7.

25 Spencer WH, Iverson HA. Diffuse melanoma of the iris, with extrabulbar extension via the optic nerve. Surv Ophthalmol 1965;10:365-71.

26 Reese AB, Howard GM. Flat uveal melanomas. Am f Ophthalmol 1967;64:1021-8.

27 Spencer WH. Primary neoplasms of the optic nerve and its sheaths: clinical features and current concepts of pathogenetic mechanisms. Trans Am Ophthalmol Soc 1972;70:490528.

28 Kolb H, Vollmar F. Beitrag zum flächenhaften malignen Melanom der Chorioidea. Albrecht Graefes Arch Klin Exp Ophthalmol 1974;191:45-52.

29 Spencer WH. Optic nerve extension of intraocular neoplasms. Am $\mathcal{f}$ Ophthalmol 1975;80:465-71.

30 Völcker HE, Naumann GOH. Klinisch unerwartete maligne Melanome der hinteren Uvea. Klin Monatsbl Augenheilkd 1976;168:311-7.

31 McLean IW, Foster WD, Zimmerman LE. Prognostic factors in small malignant melanomas of choroid and ciliary body. Arch Ophthalmol 1977;95:48-58.

32 Thomas JV, Green WR, Maumenee AE. Small choroidal melanomas. A long-term follow-up study. Arch Ophthalmol 1979;97:861-4.

33 Faber W, Kock E. Die prognostische Bedeutung histopathologischer Befunde bei malignen Melanomen der Chorioidea und des Ziliarkörpers insbesondere bei regressiven Veränderungen. Klin Monatsbl Augenheilkd 1982;181: 458-64.

34 Brown GC, Shields JA. Mechanisms of optic disc swelling with diffuse choroidal melanomas: clinicopathologic correlations. Br f Ophthalmol 1982;66:77-82.

35 Chess J, Albert DM, Bellows AR, Dallow R. Uveal melanoma: case report of extension through the optic nerve to the surgical margin in the orbital apex. Br f Ophthalmol 1984;68:272-5

36 Weinhaus RS, Seddon JM, Albert DM, Gragoudas ES, Robinson N. Prognostic factor study of survival after enucleation for juxtapapillary melanomas. Arch Ophthalmol 1985;103:1673-7.

37 Sassani JW, Weinstein JM, Graham WP. Massively invasive diffuse choroidal melanoma. Arch Ophthalmol 1985;103: 945-8.

38 Shields CL, Shields JA, Yarian DL, Augsburger JJ. Intracranial extension of choroidal melanoma via the optic nerve. Br F Ophthalmol 1987;71:172-6.

39 Fuchs U, Kivelä T, Tarkkanen A. Cytoskeleton in normal and reactive human retinal pigment epithelial cells. Invest Ophthalmol Vis Sci 1991;32:3178-86.

40 Uusitalo M, Kivelä T, Tarkkanen A. Identification of a novel element in the human eye. The inner connective tissue layer of the ciliary body characterized with antibodies to the HNK-1 epitope. Invest Ophthalmol Vis Sci 1993;34:237281.

41 Romeis B. Mikroskopische technik. 16th ed. Munich: R Oldenbourg Verlag, 1968:281.

42 Aznavoorian S, Murphy AN, Stetler-Stevenson WG, Liotta LA. Molecular aspects of tumor cell invasion and metastasis. Cancer 1993;71:1368-83.

43 Mareel MM, Van Roy FM, Bracke ME. How and when do tumor cells metastasize? Crit Rev Oncogen 1993;4:559-94.

44 Zetter BR. The cellular basis of site-specific tumor metastasis. N Engl f Med 1990;322:605-12.

5 Rusciano D, Burger MM. Why do cancer cells metastasize into particular organs? Bioessays 1992;14:185-94.

46 Riffenburgh RS. Metastatic malignant melanoma to the retina. Arch Ophthalmol 1961;66:487-9.

47 Letson $\mathrm{AD}$, Davidorf $\mathrm{FH}$. Bilateral retinal metastases from cutaneous malignant melanoma. Arch Ophthalmol 1982; 100:605-7.

48 Eide N, Syrdalen P. Intraocular metastasis from cutaneous malignant melanoma. Acta Ophthalmol (Copenh) 1990;68: $102-6$.

49 Robertson DM, Wilkinson CP, Murray JL, Gordy DD. Metastatic tumor to the retina and vitreous cavity from primary melanoma of the skin. Treatment with systemic and subconjunctival chemotherapy. Ophthalmology 1981;88: 1296-301.

50 Fishman ML, Tomaszewski MM, Kuwabara T. Malignant melanoma of the skin metastatic to the eye. Frequency in autopsy series. Arch Ophthalmol 1976;94:1309-11.

51 Kelly DE, Hageman GS, McGregor JA. Uveal compartmentalization in the hamster eye revealed by fine structural and tracer studies: implications for uveoscleral outflow. Invest Ophthalmol Vis Sci 1983;24:1288-304.

52 Fuchs U, Kivelä T, Summanen P, Immonen I, Tarkkanen A. An immunohistochemical and prognostic analysis of cytokeratin expression in malignant uveal melanoma. Am fPathol 1992;141:169-81. 